\title{
1. 水産動物筋肉中の含窒素エキス成分の分布
}

\author{
鴻 巣 章 二*
}

生物の組織や食品を細切して水で抽出すると種々の成分が溶出してくる。これからタンパク質, 脂澌, 多 螵頪, 色素,ビタミン，無機物などを除いた残りの有機物をエキス成分と称している。したがつて遊離つミ ノ酸、ペプチド，各種有機塩基，ヌクレオチドなどの含空素化合物や有機酸（高級脂肪酸を除く），糖類な どの無空素化合物がエキス成分に包含される。ただし glycogen や無機物をエキス成分として扱つている例 むあり、エキスの定義に多少あいまいな点が残されている。

ここでは木座動物筋肉**の含空素エキス成分について述べるが，ペプチド， ヌクレオチド招よび TMAO については別に取り上げられるので，必要に応でて簡単に触れるにとどめる。

この分野における最近 10 年間の研究のあとを振り返ると, 分析方法の画期的進歩が大きな推進力となつ て, 二つの点で著しい進展が見られたといえる。その一つは，アミノ酸分析が微生物法からカラムクロマト グラフ法へ，そしてその自動化一とめざましい進歩を遂げて簡易化されたことにより，遊離アミノ酸関し て多くのデータが蓄積されたことである。

第 2 の影著な進歩は，いくつかの種類でエキスの含空素成分の組成が注注完全に解明され，さらに無窒素 成分を含めた克明な分析例も二，三見られるよらになつたことである。むた微量成分の顺出，同定る容易と なり，種々の新物啠が報告されたこともこの間の進歩の一つとして举げられよう。以下とれらについて概要 を述べる。

\section{1. 遊離了ミノ酸組成}

魚類をはじめとして下等無脊椎動物にいたるまで多くの種類について，遊離アミノ酸組成が詳細に調べら れている。わが国では主として食品化学的観点から研究されているのに対し，外国では浸透王調節との関連 で分析されている例が多い。また，いくつかの種類では，部位に上る相違，季節変化，成長に伴ら変化，産 卵回遊中の変化などが調ベられている。

\section{1-1. 種類別遊離了ミ/酸組成}

主な種類のアミノ酸組成を Fig. 1 と示した（生鮮物中 $11 \mathrm{mg} \%$ 以下のアミノ酸は省略してある）。魚 類, 甲款類, 頭足類, 貝類, その他に分け，それぞれの遊離つミ八酸分布の特徵を䉍単に述べると次のと拉 りである。

魚類 各種類に共通なパターンはなく，また分類学上の位置とアミノ酸分布との間にも特に関連は認めら れない。しかし，カッオ・マグロ類やマサバ，カタクチイワシなどの活動性魚類に His が多いという古く から認められている生態との関保が顕著な㖽向として指摘できる。Tau P Lys が比較的多い種類もする が，上記の His に富さ種類を除くと，魚類は一般に遊離つミノ酸が少ないとい点よう。

なお，ペーパークロマトグラフィーによるものであるが, VUL'FSON ${ }^{15)}$ が黑海とアムール河産の 11 種に ついて定量をまた SCHAEFER ${ }^{16)}$ が北欧産の 45 種について半定量を行ない，サメ・エイ類は $\beta$-Ala や sarcosine に富むこと，低水温域の魚類に $\beta$-Ala が多い顓向が見られることなどを報告している。

甲款類 魚類に比べて遊離つミノ酸量が多いことが目だつ。そして魚類では種類ごとにかなり異なつたつ

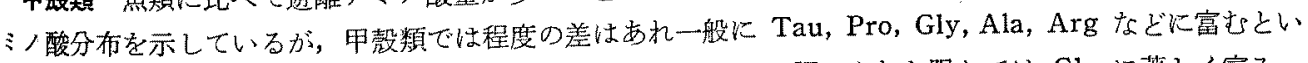
ら共通した特徵がみられる。ことに本邦産の主な食用種について調べられた限りでは Gly に著しく富み，

* 東京大学農学部

粎小動物や下等動物では全体を报つた研究が多いので, それらも含めた。また，筋肉以外の組織の研究も 必要に店じて引用した。 


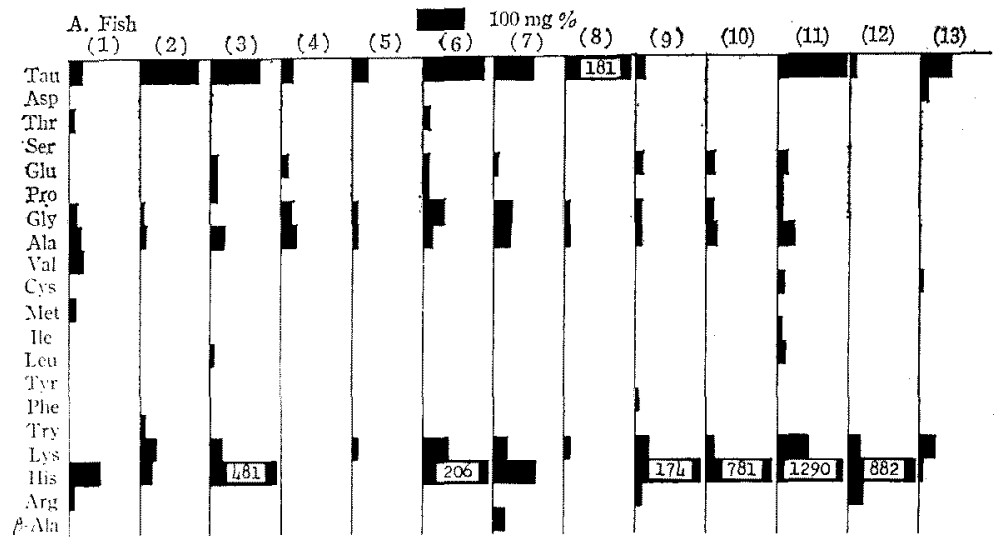

H. Nolluss $100 \mathrm{mg}$ :
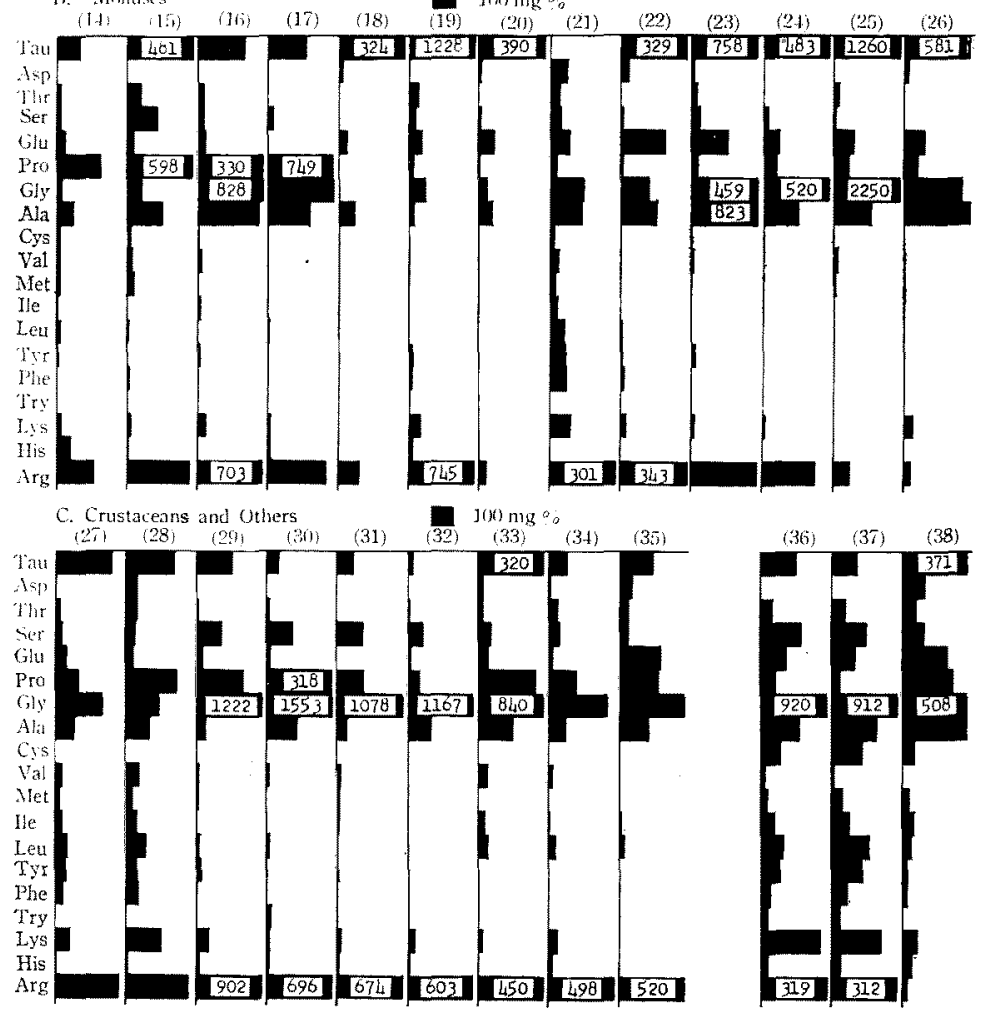

Fig. 1. Distribution of free amino acids in the muscle of aquatic animals. Amino acids less than $11 \mathrm{mg} \%$ are omitted. Figures are given to amino acids more than $150 \mathrm{mg} \%$ in $\mathrm{A}$ and those more than $300 \mathrm{mg} \%$ in B and C. See foot-notes in the next page for species. 
鮮肉中 $1 \%$ 以上に及ぶものが多い11)。

頭足類 イカ類は一般に Tau, Pro, Gly, Ala, Arg が多く。この点甲媺頑と似ているが，種類による変

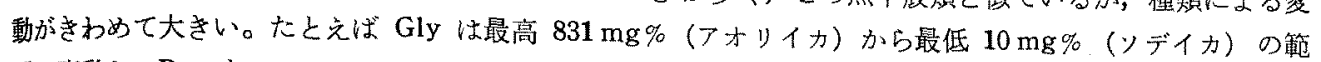
围で変動し, Pro もヒラケンサキイカの $963 \mathrm{mg} \%$ に対し，ソデイカでは痕跡しか検出されていない。 タコ類ではイイダコ ${ }^{1)}$ が分析されているが，Arg (146 mg\%) 以外のフミノ酸はすべて $30 \mathrm{mg} \%$ 以下で 少ない。

貝類 10 数種の巻貝や二枚貝の可食部について調べられたところによると, Tau, Gly, Ala, Arg が多 いなど基本的には頭足類と類似のパターンを示すといえる。しかしTau が最高含量を示す種類が多いこと， Pro が概して低含量であること，Glu が比較的多いことなど頭足類とはやや異なつた点もみられる。ただ し，高木ら ${ }^{7)}$ が分析したハマグリに Tau が恮出されていないのはただ一つの例外である。SIMPSON ら ${ }^{17}$ は㜞体動物 29 種について Tau の分布を調べ，淡水産と陸産種には検出されないが，海産と汽水産種には 多かれ少なかれ例外なく存在すると報告している。

閉殸筋の遊離アミノ酸分布についても上記の特徽がよく当てはまるが，ホタテがイでは Tau 著しく多いのが目だつ。

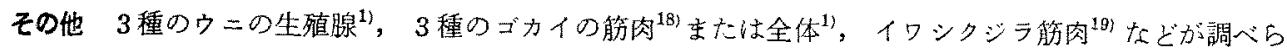
れている。

まず,ウ二の生殖腺ではアミノ酸含量が多く, 特に Gly とAla 汇富み, 他の水産動物筋肉飞概して少 ない Val, Ile, Leu, Tyr なども多いことが注目される。ゴカイ類は3種とも Tau, Gly, Ala, Pro, Glu を豊富に含をが，他の無等椎動物上は異なり，Arg $(2 \sim 22 \mathrm{mg} \%)$ が少量しか存在しない。イワシクジラ筋 肉の遊離アミノ酸ではもつとも多いもので Ala の $12 \mathrm{mg} \%$ にすぎず, エキス-N の過半を Bal, Ans, Carなどのジペブチドが占めている。

以上の活か半定量ないしは定性であるが，SIMPSON 5 ${ }^{177}$ の腔腸動物，節足動物，軟体動物，棘皮動物 17 種の研究と BERGQUIST $5^{201}$ の西インド諎島産普通海綿 50 属 67 種の研究があり, 後者で hypotaurine, pipecolic acid, $\beta$-aminobutyric acid など特殊な成分が多くの種類に検出されていることが興味深い。

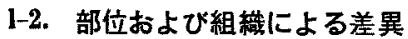

種々の魚類について普通肉と血合肉の此較が行なるれているが，いずれも後者にHis が少ないことが指 摘されている,21。市た，カタクチイワシででは血合肉飞 Tau とAla が多いという。

A. (1) Hoshi-zame, Mustelus manazo $0^{1}$, (2) Nishin, Clupea pallasi ${ }^{2)}$, (3) Katakuchi-iwashi, Engraulis japonica ${ }^{1)}$, (4) Salmo salar ${ }^{3)}$, (5) Unagi, Anguilla japonica ${ }^{1)}$ (6) Bora, Mugil cephalus ${ }^{1)}$, (7) Gadus morhua $\alpha^{4)}$, (8) Ma-dai, Chrysophrys major ${ }^{1}$, (9) Ma-aji, Trachurus japonicus ${ }^{11}$, (10) Ma-saba, Scomber japonicus ${ }^{1)}$, (11) Katsuo, Katsuwonus pelamis $^{51}$, (12) Kiwada, Neothunnus albacora ${ }^{1)}$, and (13) Aka-garei, Hippoglossoides dubi$u s^{1}$.

B. (14) Surume-ika, Ommastrephes sloani pacificus ${ }^{1)}$, (15) Kō-ika, Sepia esculentat ${ }^{1)}$, (16) Kensaki-ika, Loligo kensaki $i^{11}$, (17) Aori-ika, Sepioteuthis lessoniana ${ }^{1}$, (18) Ezo-bora, Neptunea poycostata ${ }^{6}$, (19) Kuro-awabi, Nordotis discus ${ }^{7)}$ (20) Ma-gaki, Crassostrea gigas ${ }^{7}$, (21) Hamaguri, Meretrix lusoria), (22) Asari, Tapes phitippinarum ${ }^{73}$, (23) Hokkigai, Spisula sachalinensis ${ }^{7}$, (24) Akoyagai, Pinctada fucata ${ }^{1)}$, (25) Hotategai, Pecten yessoens$i s^{83}$, and (26) Ostrea edulis ${ }^{9}$. (18)-(23), soft part except viscera; (24)-(26), adductor muscle.

C. (27) Calanus finmarchicus ${ }^{10)}$, (28) Euphausia superba ${ }^{1)}$, (29) Kuruma-ebi, Penaeus japonicus ${ }^{11)}$, (30) Yoshi-ebi, Metapenaeus monoceros ${ }^{11)}$, (31) Ise-ebi, Panulirus japonicus ${ }^{113}$, (32) Tenaga-ebi, Palaemon nipponesis ${ }^{11)}$, (33) Leander serratus ${ }^{12)}$, (34) Astacus pallipes ${ }^{13}$ (35) Shinamokuzu-gani, Eriocheir sinensis ${ }^{14)}$, (36) Bafun-uni, Strongylocentrotus pulcherrimus $^{1}$, (37) Ezobafun-uni, S. intermedius ${ }^{11}$, and (38) Iso-gokai, Perinereis brevicirrus ${ }^{1 \text {. }}$. (27) and (38), whole body; (36) and (37), gonad. 


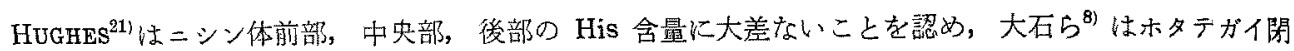
殸筋のいわゆる赤筋（横紋筋）と白筋（平滑筋）とを比較し，Gly が前者にかなり多いこと妾みている。

\section{1-3. 季節变化}

JONES ${ }^{22}$ 法 3 年以上にかたり Aberdeen 沖の lemon sole の遊離アミノ酸の変動を追跡した結果, 各ア ミノ酸はかなり变動するが，一定の明瞭な周年变化を示すのは Glu, Gly, Tau で，Tau が夏季汇增すの は淮場海水の塩分浱度が高くなるためか电知れないと推諭している。

HUGHES $^{1 /}$ はイギリス沿岸の ニシンについて 10 種の遊離つミ，酸量の変化を調ベ，His（5月下旬に最 高，10，11 月に最低）のほかに一定の季節変化を示するのはなく，また個々のアミノ酸量および合計量と もに性成熟度，雙雄，年令との間になんらの関連も見いだせなかつたと報告している。VYNCKE ${ }^{28)}$ む北海 産アブラッノザメでペプチドが春から夏にやや多いことを認めたが，遊離アミノ酸には全く李節変化を認め ていない。

次に，クルマエビについて調べた藤田 ${ }^{11)}$ は次の上うな興味ある結果を得ている。すなわち，Gly が1月 に $1500 \mathrm{mg} \%$ 前後あつたが，5月頃から減少し始め，6－9月には半減した。Argはをれと全く逆の变化 をたどり，Gly-N と Arg-N の合計は周年ほぼ一定值を示した。そして Gly の減少期とArg の増加期と は産畉期と一致していた。以上のことから両アミノ酸の変化は産畉と密接な関係があると推定されている。

一方, 遠藤ら 期の6月に多く, 10月の成体に少ないこと, 後者では Pro が 4 月が 6 月にか壮て生殖巣の成熟に伴つて 著しく減少することをみている。

\section{1-4. 成長に伴う変化}

Salmo salar ${ }^{24)}$ が parr から smolt へ，さらに成体一と成長するにつれて Tau 注隇少し，Ans が著 增するが， parr と smolt の間の変化は徐々であるのに対し，その後の変化はかなり急激であるといら。 これについて LoVE ${ }^{25)}$ は，海水に適応するための生理的贺化の一つかも知れないと述べている。

北海産アブラッノザィについて VYNCKE ${ }^{23 !}$ は雌雄に関係なく未成熟魚は成熟魚に比してアミノーN が多 く, 個々のアミノ酸では Glu, Gly, Ala, Leu が多いことを観察し, その理由として前者の蛋白代謝が活

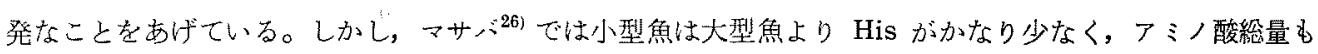
少ないと報告されている。

\section{1-5. 産卵回遊中の変化}

ベニマスの産卵溯河中の变化を追跡したWOOD ら ${ }^{27)}$ は, 初期に His の減少が著しいことを認めているが, Salmo salar について CowEY $5^{3)}$ は, 海水から淡水への移動, 生殖樂の成熟, 絶食などの影響ははつき り喼められないと述べている。

\section{1-6. 環境水の塩分濃度の影響}

遊離アミノ酸が浸透圧調節に重要な役割を演じ, 環境水の塩分濃度の变化に応じて増減することが角類を

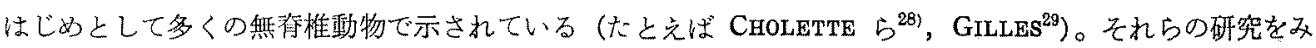
ると，すべてのアミ/酸が一様に增減するのではなく, Tau, Glu (Gln を含む), Gly, Ala, Pro などの変 化が著しいようである。

\section{1. その他の含窒素化合物}

比较的よく研究されているべタイン類とグアニジン化合物について簡単に述べるが，定量的データは glycine betaine § creatine, creatinine を除いてきわめて少ない。

ベタイン類 水産動物について広く分布を調べたものとして，GASTEIGER ら ${ }^{30)} の$ homarine の研究と $\mathrm{BEERS}^{31)}$ の各種ベタインに関する研究がある。

前者の砸究で注目されるのは, homarine が存椎動物や淡水産無沗椎動物には検出されていないことで,

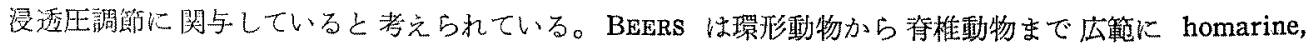
glycine betaine, carnitine, trigonelline, $\gamma$-butyrobetaine の分布を調べ，海産甲殼類にはべタインの種 
類も量も多いと述べている。

Glycine betaine については主として甲殼類や軟体類について多くの湘定結果が報告され，いずれ子重要 な含掌菜成分であることが指摘されている（エキスの組成の項参照）。

グアシシン化合物 坂口ら ${ }^{32}$ が各種の魚類について creatine を定量したところによると，いわゆる赫身 魚と白身魚との間に相違はみられないが， creatne-N のエキスーN に対する比は白身魚に高い㑯向がある という。普通肉と血合肉とでは，前者の方が creatine を多く含むようである1)。一， creatine は Salmo

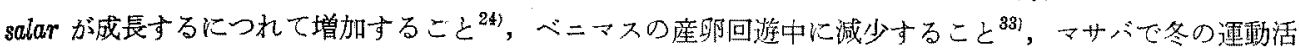
発な時期に比繋的多いこと奴よ゙が報告されている。

なお， phosphocreatineをはじめとする各種フォスファーゲンの水産動物に稀ける分布が取りまとめられ ている(3)。

次に octopine について遠藤ら ${ }^{351}$ は漁獲直後のスルメイ力 $(167 \mathrm{mg} \%)$ の含量を測定するとともに，アオ リイカの貯蔵中の変化を調ベ，眝蔵初期に急激に增加すること，ならびにこれと平行してArg が減少する ことを示している。また，THOAI $5^{36)}$ はホタテガイの閉殼筋，外套膜，肝すい臓の octopine 含量を調

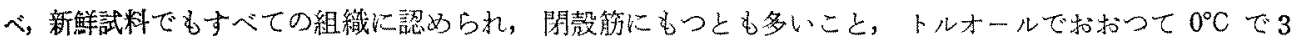

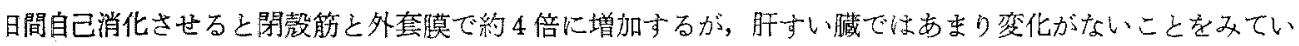

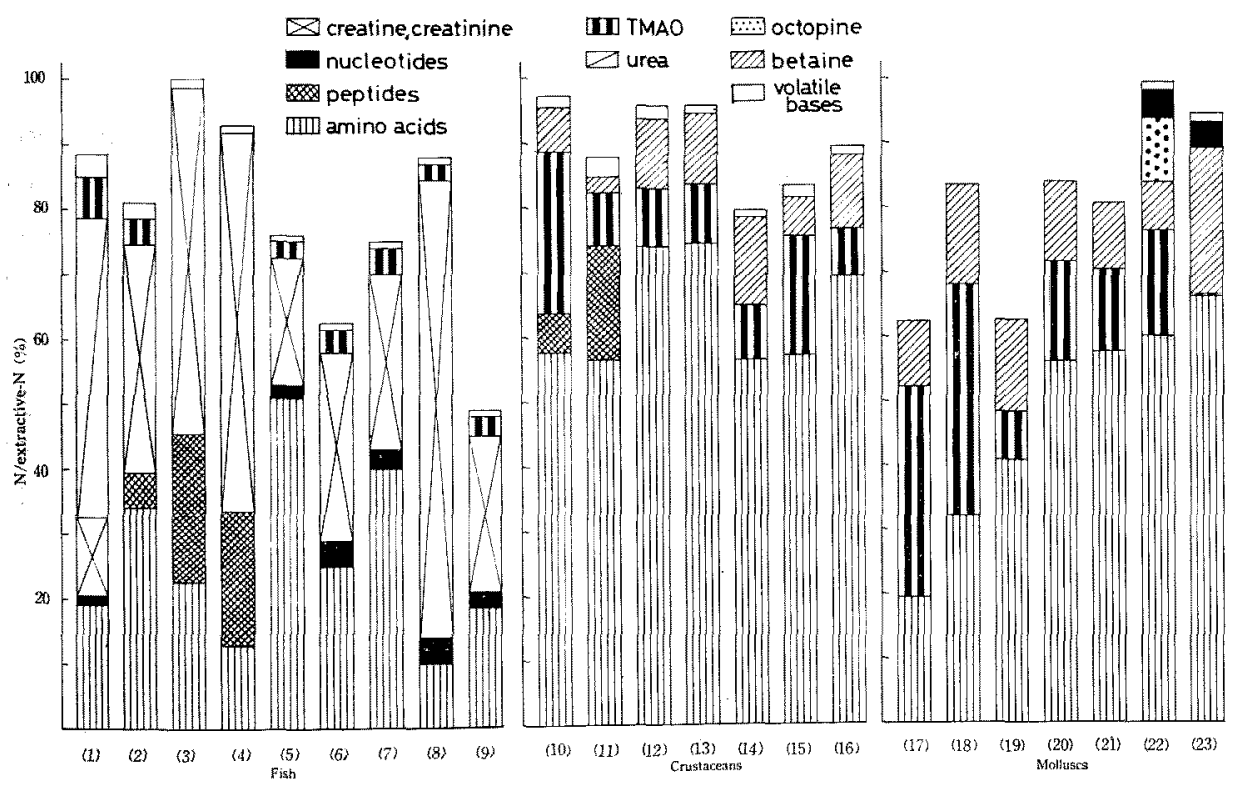

Fig. 2. Distribution of nitrogen in the muscle extracts of aquatic animals.

(1) Hoshi-zame, Mustelus manazo", (2) Katakuchi-iwashi, Engraulis japonica'), (3) Salmo salar (parr) ${ }^{24)}$, (4) S. salar (smolt) ${ }^{24)}$, (5) Ma-saba, Scomber japonicus ${ }^{1)}$, (6) $\mathrm{Ma}^{-}$ aji, Trachurus japonicus ${ }^{1)}$, (7) Kiwada, Neothunnus albacora ${ }^{1)}$, (8) Mebaru, Sebastes inermis $^{1)}$, (9) Aka-garei, Hippoglossoides dubius ${ }^{1)}$ (10) Calanus finmarchicus (whole body) ${ }^{10)}$, (11) Euphausia superba ${ }^{1)}$, (12) Kuruma-ebi, Penaeus japonicus ${ }^{11)}$, (13) Yoshi-ebi, Metapenaeus monoceros ${ }^{11)}$, (14) Ise-ebi, Panulirus japonicus ${ }^{11)}$, (15) Toyama-ebi, Pandalus hypsinotus $^{11)}$, (16) Uchiwa-ebi, Ibacus ciliatus ${ }^{11}$, (17) Surume-ika, Ommastrephes sloani pacificus ${ }^{1)}$, (18) Sode-ika, Thysanoteuthis rhombus ${ }^{1)}$, (19) Kō-ika, Sepia esculenta ${ }^{1)}$, (20) Hirakensakiika, Loligo chinensis ${ }^{1)}$, (21) Kensaki-ika, Loligo kensaki ${ }^{1)}$, (22) Aori-ika, Sepioteuthis lessoniana ${ }^{383}$, and (23) Kuro-awabi, Nordotis discus ${ }^{1)}$. 


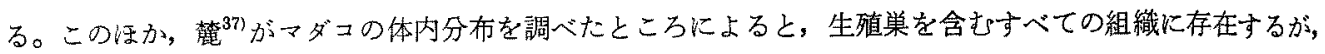
筋肉がもつ上も多く，雌雄差は認められていない。

111. エキスの組成

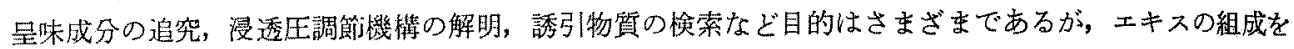
詳細に分析した例がいくつか見られる。含窒素成分に限つた研究と無窒素成分も含めた研究とがある。

111-1. 含空素成分の分布

遊離アミノ酸をはじめとして各種の含壆素成分を分析した例を Fig. 2 に示す（图ではエキスーN に対す る各成分の N の割合で示してある。

魚類 メバルやホシザメでは分析された成分だけでエキスーNの90\%近くが回収されているが，マア ジやアカガレイではわずかに 50 60\%にしか澾せず，著しい相違がみられる。これに対し，Salmo salar の parr では遊離アミノ酸, Ans, creatine, creatinine, アミド-N, 揮発性塩基-N でエキス-N のほとん ど全部が説明できると報告されている。

甲款類 魚類と逴つて遊離つミ，酸がエキス-N の過半を占める種頑が多く，これに TMAO と glycine betaine を加えただけで 80〜95\%の の が回収されている。

軟体類 イカ類では, 遊離了ミ>酸, TMAO, glycine betaine の3者の N の合計は 60 80\%で, 甲 殼類よりや低い。残る 20 40\%の N のうち octopine やヌクレオチドの占める部分が多いと考えられ， これらも測定したアオリイカ ${ }^{38)}$ ではほぼ完全にN 分布が明らかにされている。

貝類ではクロアワビが詳細に調ベられている。

\section{III-2. 無空素成分も含めた分布}

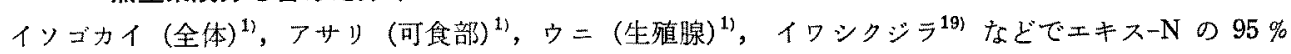
以上の分布が明らかにされ，その上糖や有機酸も分析されている。イワシクジラでは無機物む定量され，湘 定された成分の合計は土キ又乾物量の $97.5 \%$ に及び，エキスのもつと曲詳細な分析例の一つとして注目 される(須山：“水産動物筋肉中の低級ペプチド”の Table 2 参照)。なお，イワシクシラでは Bal が, ウニではアミ/酸がそれぞれ卓越していることが $\mathrm{N}$ 分布の特微である。

\section{III-3.エキスの詳細な分析結果の応用例}

典型的な例として小俣1) のウ二の呈味成分の研究をあげることができる。彼はまず，分析値に従つて調製 した合成エキスの味が天然エキスのそれと変わらないことを確かめた後，合成エキスから個々の成分を除い て味の変化を調バてゆくいわゆる“omission test”を行ない,ウ二特有の味の発現には徽量の Met が不可 久であるといらきわめて興味ある結果を得ている。

これと同種の研究はアワビ AMP の重要性が明らかにされ，後者では多量に含まれる His が味之無関係であると結諭されている。

一方，筆者ら ${ }^{411}$ はアサリエキスがウナギを強く誘引することに注目し，有効物質を同定する目的て同様の omission test を行ない,アミノ酸の混合物が有効なことを示している。

\section{IV. 新たに発見された空素成分}

ここ約 10 年間に水産動物から発見された新物質あるいは水産動物に初めて存在が示された物質は次のと おり約 20 種にも及んでいる(括弧内は材料動物名)。

D-Cysteinolic acid $(イ ト マ キ ヒ ト テ ゙)^{1}$, N-methyltaurine, N, N-dimethyltaurine (海綿の一種 Calyx nicacensis) ${ }^{42)}$, taurobetaine (石灰海綿の一種) ${ }^{43)}, \beta$-sulfoalaninamide $(ス ル メ イ カ)^{44)}, 2$-aminoethylphosphonic acid (イソギンチャクの一種 Anthopleura elegantissima ${ }^{45)}, 2$-amino-3-phosphonopropionic acid (スナギンチャクの一種 Zoanthus sociatus) ${ }^{45}$, 2-methylaminoethylphosphonic acid, 2-dimethylaminoethylphosphonic acid, 2-trimethylaminoethylphosphonic acid (イソギンチャクの一種 A. xanthogrammica $)^{45)}$, glycery1-(2-aminoethyl)-phosphonate (イソギンチャクの一種 A. elegantissima $)^{45)}$, $\gamma$-hydroxyarginine $(ム ラ サ キ ク ル マ ナ マ コ)^{46)}, \beta$-guanidinopropionic acid, hydroxyagmatine ( $ヨ$ マイ 
ソギソチャク ${ }^{47}$, hypotaurocyamine, phosphohypotaurocyamine (ホシムシの一種 Phascolosoma vulgare $)^{48)}$, herzynine, ergothioneine (カブトガニの一種 Limulus polyphemus) ${ }^{49}$, $\beta$-aminoisobutyric

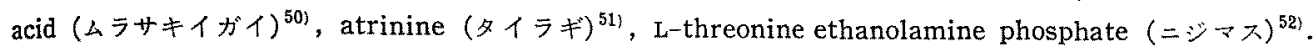

v.むす び

わが国におけるこの分野の研究では，主要漁爑対象種について遊離〉ミノ酸，TMAO、ヌクレオチドなど 主な成分がひとわたり調べら机て一段落し，今後の研究の方向を模索しているかのごとく，現在きわめて低 調である。しかし，遊離アミノ酸だけをみても，これまでに分析された種類は，水産動物が多種多様なのに 比較するとまことに微々たるもので，比較生化学的観点からな招多くのデータ一特に非食用種のそれーが蓄 耫されることが望をしい。この祭，同一試料についてできるだけ多くの成分が測定されるならば，そのデー 夕は一層有用なものとなるであろら。

一方，食品化学的見地から呈味成分を対象とした研究では，従来味覚試験が伴わなかつたきらいがある。 上述のウ二の研究で例示されたよらな成分分析と味賞試験とを結び付けた研究が，今後主な食用種や水産加 工品について行なわれることが望ましい。

エキスの組成をみて常に奇異に感ずることは，エビ類の Gly，カッオ・マグロ類の His, 鯨類のジペブチ ドの上らにある種類に特定の成分が著しく多く蓄積されていることである。それを支配している因子やその 生理的意義の解明は困難な問題とは思われるが，今後ぜひ取り組さべき研究課題と考学る。

文献

1)* 大石圭一： New Food Ind., 10 (12), 1 12 (1968).

2）木田健治・田元 蘶： 北水試月報, 24, 374 381（1967）.

3) C. B. Cowet, K. W. Daisley, and G. Parry: Comp. Biochem. Physiol., 7, 29 38 (1962).

4) N. Dambergs and P. Odense: J. Fish. Res. Bd. Canada., 25, $935 \sim 942$ (1968).

5) 鸱黉章二・橋本芳郎：本誌，25，307 311 (1959).

6) 奥村彩子・村田喜一・高木光造・大石圭一：北大水産巢報，17，147 151 (1966).

7) 高木光造・飯田 優・村山花子・相馬方加：同誌，21，128１32 (1970).

8) 大石主一・飯田 優・吉村彩子：本誌, 36, 1226 1230 (1970).

9) S. BricteuX-GréGoire, G. Duchâteax-Bosson, C. Jeuniaux, and M. Florkin: Arch. Intern. Physiol. Biochim., 72, 267 275(1964).

10) C. B. Cowey: J. Mar. Biol. Ass. U. K., 43, $485 \sim 493$ (1963).

11）藤田真夫：“エビ類の筋肉エキス中の空素化合物比関する研究”，107 pp. (1961).

12) C. Jeuniaux, S. Bricteux-Grégotre, and M. Florkin: Cahiers Biol. Mar., 2, $373 \sim 379$ (1961).

13) C. B. Cowey: Comp. Biochem. Physiol., 2, 173 180 (1961).

14) S. Bricteux-Grégoire, G. Duchâteau-Bosson, C. Jeuniaux, and M. Florkin: Arch. Intern. Physiol. Biochim., 70, 273 286 (1962).

15) P. L. Vul'Fson: Biokhimiya, 26, 300 304 (1961).

16) H. SCHAgFER: Helgoländer Wiss. Meeresuntersuch., 8, 257 275, 280 286 (1962).

17) J. W. Simpson, K. Allen, and J. Awapara: Biol. Bull., 117, $371 \sim 381$ (1959).

18) C. JeuniauX, G. DuchâteAu-Bosson, and M. Florkin: J. Biochem., 49, 527 531 (1961).

19) M. SuYama, M. Murayama, and S. Takeuchi: This Bull., 36, 1250 1257 (1970).

20) P.R. BERGQUIST and W. D. HartMaN: Mar. Biol., 3, 247 268 (1969).

21) R. B. Hughes: J. Sci. Fd Agric., 15, 293 299 (1964).

22) N. R. JONES: ibid., 10, 282 286 (1959).

23) W. VYNCKE: Mar. Biol., 6, 248 255 (1970).

24) C. B. Cowey and G. PARry: Comp. Bichem. Physiol., 8, 47 51 (1963).

25) R. M. Love: The Chemical Biology of Fishes, 547 pp., Academic Press, London (1970).

26) 坂口守彦・清水 亘: 本誌, 31，72 75 (1965).

27) J.D. Wood, D. W. Duncan, and M. Jackson: J. Fish. Res. Bd. Canada., 17, $347 \sim 351$ (1960).

*この総説「魚介肉のエキス成分」に引用されている論文はずてて1）とし，個々の引用を省略した。 
28) C. Cholette, A. Gagnon, and P. Germain: Comp. Biochem. Physiol., 33. 333 346 (1970).

29) R. Gilles: Arch. Intern. Physiol. Biochim., 78, $91 \sim 99$ (1970).

30) E. L. Gasteiger, P. C. HaAke, and J. A. Gergen: Ann. N. Y. Acad. Sei., 90, 622 636 (1960).

31) J. R. Beers: Comp. Biochem. Physiol., 21, 11 21 (1967).

32) M. Sakaguchi, M. Hujita, and W. Simidu: This Bull., 30, $999 \sim 1002$ (1964).

33) V.M. Chang, H. Tsuyuki, and D. R. Idler: J. Fish. Res. Bd. Canada., 17, 565 582 (1960).

34) N. V. Thoal and J. Roche: Ann. N. Y. Acad. Sci., 90, 923 928 (1960).

35) 還藤金次・清水 亘: 本誌, 29,362 365 (1963).

36) N. V. ThoAI and Y. Robin: Bull. Soc. Chim. Biol., 41, 735 742 (1959).

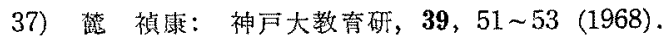

38) 還藤金次・藤田真夫・清水 亘：本誌，29，366 370 (1963).

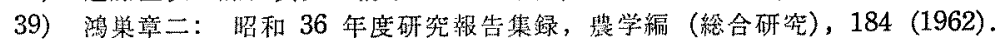

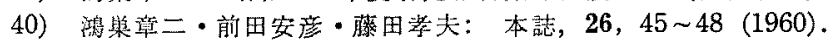

41）橋本芳郎・䳺笺章二・伏谷伸宏・能勢健呞：本誌，34，78 83 (1968).

42) D. ACkermann and R. Pant: Z. Physiol. Chem., 326, 197 199 (1961).

43) D. AcKermann and P. H. LIst: ibid., 317, 78 81 (1959).

44) Y. KoJIMA and H. KuSAKABE: J. Sci. Res. Inst., 51, 189 194 (1957).

45) E. Roberts and J.S. Kitrredge: U.S. Clearinghouse Fed. Sci. Tech. Inform., AD 1969, AD-697976 (1969).

46) Y. FujtTA: Bull. Chem. Soc. Japan, 32, 439 442(1959); 33, 1379 1381 (1960).

47) S. Makisumi: J. Biochem., 49, 284 291 (1961).

48) Y. Robin and N. V. ThoAI: Biochim. Biophys. Acta, 63, 481 488 (1962).

49) D. Ackermann and P. H. List: Z. Physiol. Chem., 313, 30 36 (1958).

50) J. Awapara and K. Allen: Science, 130, 1250 (1959).

51) S. Konosu, Y.-N. Chen, and K. Watanabe: This Bull., 36, 940 944 (1970).

52) H. Rosenberg, A. H. Ennor, D. D. Hagerman, and S. Sugai: Biochem. J., 84, 536 541 (1962). 